\title{
Sphingomyelinases in Human Tissues. III. Expression of Niemann-Pick Disease in Cultured Skin Fibroblasts
}

\author{
J. W. CALLAHAN ${ }^{(22)}$ AND M. KHALIL \\ Research Institute, Hospital for Sick Children, Toronto, Ontario, Canada
}

\section{Extract}

\begin{abstract}
Sphingomyelinase was effectively extracted from cultured fibroblasts homogenized in $1 \%$ glycine. The average specific activity was 24.6 nmol substrate hydrolyzed per hr per mg protein. Cultured cells from two cases of Niemann-Pick disease type $A$ and one case of type $B$ had markedly reduced enzyme activity, whereas, in type $E$ cells, total activity was twice normal. Sphingomyelinase was resolved by isoelectric focusing into three peaks of activity (I-III), where I and II were the major forms. Species I had a pI of 4.6 , II a pI of 4.8 , and III a pI of 5.0. All three peaks, although markedly reduced, were present in cell extracts from both types A and B. All species of enzyme in B cells were found at higher levels than in A cells. Cultured cells from a case of type $E$ contained sphingomyelinase I at a level several fold higher than normal, species II was absent, whereas III was found at near normal levels.
\end{abstract}

\section{Speculation}

The data suggest that multiple forms of sphingomyelinase exist in cultured cells. Each species may contain polypeptide sequences in common since all forms are affected in fibroblasts in both types $\mathrm{A}$ and $\mathbf{B}$. It is also likely that each sphingomyelinase species possesses some unique structure since a specific deficiency of species II was found in a case of type $E$. Type $C$ and type $E$ Niemann-Pick disease appear to be related since both involve a specific deficiency of sphingomyelinase II.

Several clinical entities are known within the general designation of Niemann-Pick disease (8). All are characterized by sphingomyelin lipidosis, foam cells in marrow, and hepatosplenomegaly. All types differ with respect to the onset and severity of central nervous system involvement, degree of sphingomyelin storage, and tissue sphingomyelinase levels. Brady et al. (2) in 1966 demonstrated for the first time that sphingomyelinase activity was exceedingly low in tissues from patients with the infantile form of this disease. This form is called type A according to the classification of Crocker (6). This observation was quickly confirmed by other workers who noted further low enzyme levels in patients with a non-neuronopathic form (type B), but normal levels in a juvenile variant (type C) (12). Two additional forms of Niemann-Pick disease have been recognized (types D and E), but the enzyme defects have not been determined previously $(8,10)$.

We recently separated sphingomyelinase by isoelectric focusing of tissue extracts into several peaks of activity $(3,4)$. These have been designated $\mathrm{I}-\mathrm{V}$ according to their increasing isoelectric points. Sphingomyelinases I and II are the major forms in liver and brain, whereas species III-V are the minor forms. In liver and brain from three patients with type C sphingomyelinase II was markedly reduced or completely absent. We proposed that the genetic defect in type $\mathrm{C}$ was the specific deficiency of this sphingomyelinase.
Cultured skin fibroblasts have proven to be excellent sources of tissue for elucidation of enzyme defects in several lysosomal storage diseases $(1,5,13,14)$. In Niemann-Pick disease, type A, total sphingomyelinase is barely detectable, whereas in cultured cells from type B the activity, although higher than in Type A, is still $3-10 \%$ of the normal level (13). Total activity in cells from type $C$ is within normal limits. Prenatal diagnosis of type $A$ has been successfully achieved by analysis of cultured amniocytes in a family where an index case has been identified previously (7). Prenatal diagnosis of type B is similarly possible. However, in the absence of index cases and for the other types of Niemann-Pick disease, neither antenatal diagnosis nor reliable carrier detection has been achieved.

In the present communication, we have attempted to determine the mode of expression of the genetic defects in some forms of Niemann-Pick disease in cultured skin fibroblasts. The data suggest that specific diagnosis of the various types can be made by analysis of cultured cells.

\section{MATERIALS AND METHODS}

\section{PATIENT MATERIAL}

Fibroblast cultures were derived from patients in whom a diagnosis of Niemann-Pick disease was made either chemically or by enzyme assay. The two patients with type A, case $I(D S)$ and case $2(M M)$, and the one patient with type $\mathrm{B}(S C)$ were referred to us by Dr. J. A. Lowden of this hospital. Fibroblasts from the case of type $\mathrm{E}(M c M)$ were obtained from Dr. M. J. Wong and Dr. S. Wood, University of British Columbia, Vancouver, Canada (15). $M c M$ is a 44-year-old woman who has a 2-year history of progressive mental deterioration, slight hypotonia, and ataxia. Her spleen is just palpable below the left costal margin. A brother was found previously to have the same clinical features and foam cells in the marrow; a diagnosis of Niemann-Pick disease was made.

\section{CHEMICALS}

Bovine brain sphingomyelin, synthetic glycosides (nitrophenyl $\beta$-galactopyranoside and $N$-acetyl- $\beta$-D-glucosaminide), and crystalline bovine serum albumin were purchased from Sigma Chemical Co. (16). Methylumbelliferyl- $\alpha$-mannopyranoside was obtained from Koch-Light Laboratories (17). Carrier ampholines were a product of LKB Instruments (18).

\section{CELL CULTURE}

Skin fibroblast cultures were maintained in $\alpha$ medium with Earl's salts supplemented with $15 \%$ fetal calf serum (19). After removal of the cells from monolayer by trypsin treatment $(0.25 \%$, $5 \mathrm{~min}, 37^{\circ}$ ) the cells were collected by centrifugation and washed with phosphate-buffered saline. The final cell pellets were then stored frozen until analyzed. All fibroblast cultures used in this 
ork were devoid of mycoplasma contamination as judged by nrichment culture in four media with and without yeast extract nd supplemented with horse or porcine serum (19).

\section{EXTRACTION OF CULTURED CELLS}

To determine suitable conditions for the recovery of sphinomyelinase, cells from three control strains were grown in $100-\mathrm{mm}$ ulture dishes, harvested at confluency as above, and pooled. The ooled cells were then suspended in $2 \mathrm{ml}$ distilled water and eight 1.2- $\mathrm{ml}$ aliquots were taken. Four such aliquots were lyophilized in ared tubes and their weights determined. The four remaining liquots were stored frozen at $-10^{\circ}$. The dry weights of the frozen Ionlyophilized cells were calculated from the average dry weight of he lyophilized aliquots. Both frozen and lyophilized cells were omogenized (Teflon ball homogenizer with Thomas tubes, 10 trokes at $1.500 \mathrm{rpm}$ ) at $2.5 \mathrm{mg}$ dry weight $/ \mathrm{ml}$ of extracting fluid in he following media: distilled water, $1 \%$ glycine, $0.05 \mathrm{M}$ citratephosphate buffer, $\mathrm{pH} 4.5$, containing $0.25 \%(\mathrm{v} / \mathrm{v})$ Triton X-100 without and with sonication (twice, $30 \mathrm{sec}$, Branson sonifier, $30 \mathrm{~W}$ output) in an ice water bath. The extracts were centrifuged at $31,500 \times g$ for $45 \mathrm{~min}$ at $2^{\circ}$. The supernatant fluids and the pellets (rehomogenized in the appropriate medium) were collected and analyzed.

For isoelectric focusing experiments, the lyophilized cells ( $10-20$ $\mathrm{mg}$ dry weight) were homogenized in Ten Broeck glass tubes (20 strokes $)$ with $1 \%$ glycine $(2.5 \mathrm{mg} / \mathrm{ml})$ and the extracts were centrifuged for $30 \mathrm{~min}$ as described above. Clear supernatant fluids were collected and used as an enzyme source. The cell pellets were suspended in $1 \%$ glycine and retained for analysis.

\section{ISOELECTRIC FOCUSING}

Isoelectric focusing was carried out in a Uniphor column electrophoresis system as described previously $(3,4)$. A pH range of 4-8 was used in all experiments.

The enzyme was exposed to current for $40-43 \mathrm{hr}$ with a final potential of $600 \mathrm{~V}$. The temperature of the column was maintained between $3-4^{\circ}$ by a Haake FK 10 circulating water bath. The column was eluted from below at a flow rate of $1 \mathrm{ml} / \mathrm{min}$ and 1.0-1.2-ml fractions were collected. Enzyme activities were determined in the presence of ampholines and sucrose within $24 \mathrm{hr}$ of collection. The $\mathrm{pH}$ of the fractions was measured with a combination microelectrode in an ice water bath. In general, $\mathrm{pH}$ measurements were made on alternate fractions.

\section{ENZYME ASSAYS}

Sphingomyelinase was measured according to the method described earlier $(3,4)$. Tritium-labeled sphingomyelin was repuri- fied by preparative thin layer chromatography and diluted to a final specific activity of $1,500 \mathrm{cpm} / \mathrm{nmol}$. The assay mixture contained, in a final volume of $0.2 \mathrm{ml}: 125 \mathrm{mM}$ acetate buffer, $\mathrm{pH}$ $5.0 ; 0.167 \mathrm{mM}$ sphingomyelin $(50,000 \mathrm{cpm}) ; 0.2 \mathrm{mg}$ Triton $\mathrm{X}-100$; and $50 \mu \mathrm{l}$ column eluate. Incubation was for $1 \mathrm{hr}$ at $37^{\circ}$ for normal cells and 2-4 hr for enzyme-deficient cells. The blank value averaged $60 \mathrm{cpm}$ which represents $0.04 \mathrm{nmol}$ product. Counting efficiency was $40 \%$.

$\alpha$-Mannosidase was measured with methylumbelliferyl $\alpha$-Dmannoside at $\mathrm{pH} 3.6$ according to the method of Thomas et al. (14). An $0.05-\mathrm{ml}$ aliquot of column eluate was incubated at $37^{\circ}$ for $1 \mathrm{hr}$. The reaction was stopped by the addition of $2 \mathrm{ml} 0.1 \mathrm{M}$ 2-amino-2-methyl-1-propranol-HCl buffer, $\mathrm{pH}$ 10.4. Fluorescence was measured with a Farrand fluorometer according to the method of Robins et al. (11).

$\beta$-Glucosaminidase was assayed in a final volume of $0.2 \mathrm{ml}$ containing $100 \mathrm{mM}$ citrate-phosphate (Mc Ilvaine) buffer, $\mathrm{pH}$ $4.4,1.25 \mathrm{mM}$ substrate, $20 \mu 1$ elute, and was incubated for $1 \mathrm{hr}$. $\beta$-Galactosidase was also assayed in $0.2 \mathrm{ml}$ with $100 \mathrm{mM}$ acetate buffer, $\mathrm{pH} 4.0,1.25 \mathrm{mM}$ substrate, and $50 \mu$ l eluate. Incubation at $37^{\circ}$ was carried out for $2 \mathrm{hr}$. The above reactions were terminated by the addition of $0.25 \mathrm{M}$ glycine-carbonate buffer, $\mathrm{pH} 10$, and the absorbances were read at $400 \mathrm{~nm}$. One unit of activity is the nanomoles of sphingomyelin hydrolyzed or nitrophenol released per hr at $37^{\circ}$. Specific activity is measured in units per $\mathrm{mg}$ protein. Protein was measured according to the Lowry et al. procedure (9).

\section{RESULTS}

\section{EXTRACTION OF SPHINGOMYELINASE FROM CULTURED FIBROBLASTS}

Several extraction methods were used to determine the optimum conditions for recovery of sphingomyelinase from cultured cells (Table 1). Homogenization of lyophilized cells in water or glycine gave higher specific activity for sphingomyelinase than did the citrate-phosphate buffer containing Triton X-100, although total yields of enzyme were comparable. Sonication of the buffer extract did not improve the yield of sphingomyelinase. A slightly greater yield of enzyme was achieved with lyophilized cells homogenized in water or glycine. Enzyme activity was linear with protein concentration for up to $2 \mathrm{hr}$ in extracts prepared in water or glycine. In extracts prepared with citrate-phosphate buffer containing Triton $\mathrm{X}-100$, linearity was not maintained at higher protein concentrations. This may be because of the presence of phosphate anions which reversibly inhibit sphingomyelinase (12).

For $\beta$-hexosaminidase, maximum yields and highest specific activities were achieved with citrate-phosphate-Triton X-100 as

Table 1. Extraction of acid hydrolases from cultured fibroblasts ${ }^{1}$

\begin{tabular}{|c|c|c|c|c|c|c|}
\hline \multirow[b]{2}{*}{ Treatment } & \multicolumn{2}{|c|}{$\mathrm{SM}$} & \multicolumn{2}{|c|}{$\beta$-Hex } & \multicolumn{2}{|c|}{$\beta$-Gal } \\
\hline & Tot Un & Sp Act & Tot Un & Sp Act & Tot Un & Sp Act \\
\hline \multicolumn{7}{|l|}{ Frozen cells } \\
\hline Water & 14.3 & 23.7 & 2,591 & 4,300 & 164 & 272 \\
\hline Glycine & 12.7 & 25.4 & 1,769 & 3,545 & 216 & 433 \\
\hline Buffer & 11.9 & 13.6 & 5,043 & 5,735 & 153 & 175 \\
\hline Buffer and sonication & 10.0 & 11.8 & 4,407 & 5,207 & 137 & 161 \\
\hline \multicolumn{7}{|l|}{ Lyophilized cells } \\
\hline Water & 16.2 & 23.6 & 2,516 & 3,664 & 118 & 171 \\
\hline Glycine & 15.9 & 29.0 & 2,301 & 4,212 & 181 & 331 \\
\hline Buffer & 12.0 & 11.5 & 4,252 & 5,184 & 102 & 124 \\
\hline Buffer and sonication & 12.5 & 12.6 & 4,874 & 4,721 & 101 & 102 \\
\hline
\end{tabular}

${ }^{1}$ Cultured cells were obtained from three normal strains which were pooled and processed as outlined under Methods. All values are averages of specific activities determined at five protein concentrations. SM: sphingomyelinase; $\beta$-Hex: $\beta$-hexosaminidase; $\beta$-Gal: $\beta$-galactosidase; Tot Un: total unsaturated; Sp Act: specific activity. 
extraction fluid, whereas glycine gave the best results for $\beta$-galactosidase. We have shown previously for brain and liver that homogenization in citrate-phosphate buffer containing Triton X-100 followed by dialysis against $1 \%$ glycine gives excellent yields of sphingomyelinase (4). Since sufficiently high yields and specific activities were achieved in lyophilized cells homogenized in glycine alone, this extraction method was employed in all subsequent experiments.

Sphingomyelinase activity averaged 24.6 units/mg protein in the four normal controls examined with a remarkably narrow activity range (21.5-27.6) compared with the wide range of specific activities observed for both $\beta$-hexosaminidase and $\beta$-galactosidase (Table 2). Sphingomyelinase and the other enzymes determined appear to be stable for periods up to 1 year when stored as a frozen cell pellet at $-10^{\circ}$. Sphingomyelinase showed a broad $\mathrm{pH}$ optimum between $\mathrm{pH} 4.8$ and 5.0 when measured in the crude extract and in the supernatant fluid and pellet fractions, derived from it (Fig. 1). The $K_{m}$ value of crude sphingomyelinase was $0.015 \mathrm{mM}$ at $\mathrm{pH} 5.0$.

Cultured cells derived from two patients with type A NiemannPick disease displayed barely detectable levels of sphingomyelinase ( $1.5 \%$ of normal), whereas cells derived from one patient with type $\mathrm{B}$ had a slightly higher level (3.4\% of normal). In type E cells, total sphingomyelinase was elevated about twofold over normal in the range of the three pathologic controls examined. Total $\beta$-hexosaminidase and $\beta$-galactosidase were near normal in cells from the various types of Niemann-Pick disease.

\section{ISOELECTRIC FOCUSING OF SPHINGOMYELINASE IN EXTRACTS OH CULTURED FIBROBLASTS}

The isoelectric focusing pattern obtained in a representative experiment is shown in Figure 2. Sphingomyelinase can be partially resolved into two major peaks, the first (I) having a pI of

Table 2. Activities of lysosomal hydrolases in extracts of lyophilized cells ${ }^{1}$

\begin{tabular}{|c|c|c|c|}
\hline \multirow[b]{2}{*}{ Cell strain } & \multicolumn{3}{|c|}{ Specific activities ${ }^{2}$} \\
\hline & SM & $\beta$-Hex & $\beta$-Gal \\
\hline \multicolumn{4}{|l|}{ Control } \\
\hline \multicolumn{4}{|l|}{ Normal } \\
\hline 1 & 25.8 & 1,096 & 160 \\
\hline 2 & 27.6 & 2,250 & 275 \\
\hline $3^{3}$ & 21.5 & 7,028 & 227 \\
\hline 4 & 23.6 & & 357 \\
\hline Cystic fibrosis & 58.8 & 3,619 & 876 \\
\hline $\mathrm{G}_{\mathrm{cm} 1}$ gangliosidosis $^{3}$ & 62.3 & 15,525 & 20 \\
\hline $\mathrm{G}_{\mathrm{m} 1}$ gangliosidosis $^{3}$ & 31.2 & 2,930 & 324 \\
\hline \multicolumn{4}{|l|}{ Niemann-Pick disease } \\
\hline \multicolumn{4}{|l|}{ Tyре A } \\
\hline 1 & 0.35 & 3,125 & 400 \\
\hline 2 & 0.40 & 6,325 & 355 \\
\hline Type B & 0.83 & 2,361 & 342 \\
\hline Type E & 55.7 & 3,866 & 461 \\
\hline
\end{tabular}

${ }^{1}$ Cultured fibroblasts were lyophilized in tared tubes and the dry weight determined. The dried powder was homogenized in Ten Broeck glass tubes with cold $1 \%$ glycine and then centrifuged. Enzyme activities were determined on the supernatant fluids. Values are averages of specific activities determined at five protein concentrations. SM: sphingomyelinase; $\beta$-Hex; $\beta$-hexosaminidase; $\beta$-Gal: $\beta$-galactosidase.

${ }^{2}$ Specific activity is the nanomoles of substrate hydrolyzed (sphingomyelin) or product released ( $p$-nitrophenol) per hr per mg protein.

${ }^{3}$ Cells were stored frozen for 12 months before analysis.
4.5 (range 4.5-4.6) and the second (II) a pl of 4.8 (range 4.7-4.8) A minor peak of activity (III) is found as a shoulder of the seconc major species at a pI of 5.0-5.2. In cultured cells no othe sphingomyelinases have been observed to date. Recovery o sphingomyelinase has consistently been in the range of $60-70 \%$ ir these experiments. This yield is lower than that achieved with brair and liver but may be attributed to the low amounts of protein used Under the experimental conditions employed, $\beta$-hexosaminidase $\mathrm{A}$ (pI 5.0) constitutes over $85 \%$ of the total hexosaminidase with the rest as hexosaminidase B (pI 7.6). $\beta$-Galactosidase shows a single major peak with a pI of 4.7 , whereas $\alpha$-mannosidase is resolved into two major species: the acidic form has a pI of 5.0-5.1, while the more basic form has an isoelectric point of 5.5-5.8.

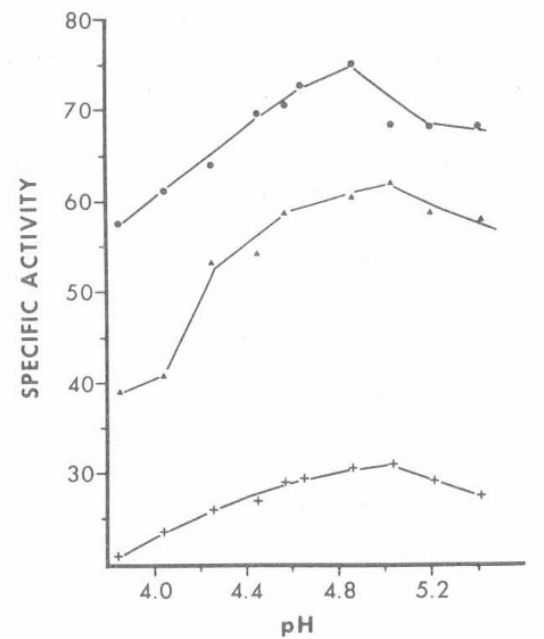

Fig. 1. pH optimum of sphingomyelinase in cultured fibroblasts. Cells derived from a control cell strain $\left(\mathrm{G}_{\mathrm{M} 1}\right.$, type 1$)$ were processed as described. Enzyme activity was quantitated in the crude extract $(-)$ ) and the supernatant fluid $(\mathbf{\Lambda}-\mathbf{\Lambda})$ and pellet extract $(+-+)$ derived from it. Acetate buffers of varying $\mathrm{pH}$ values were used.

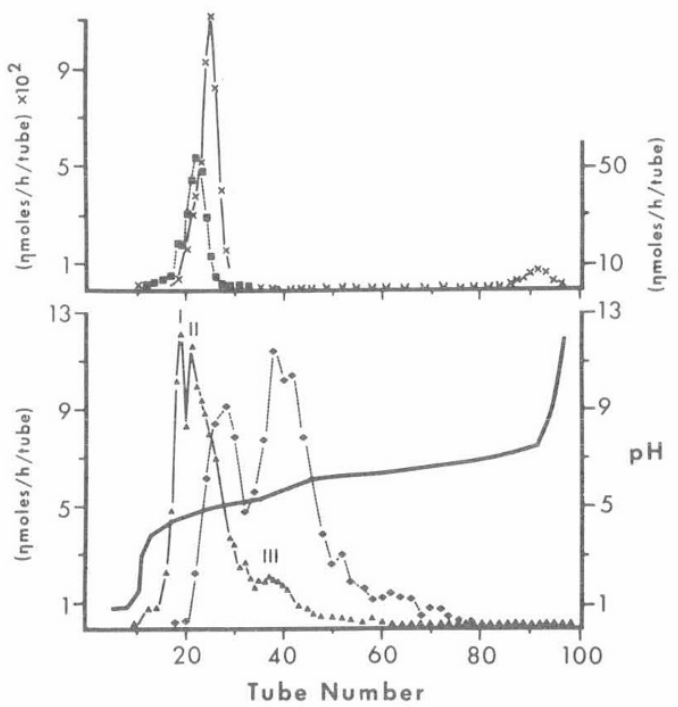

Fig. 2. Electrofocusing of hydrolases from normal fibroblasts. Cultured cells from a normal cell strain were processed as described. Enzyme activities were measured in eluates in the presence of ampholines and sucrose. In the lower panel, sphingomyelinase ( resolved into three peaks (I, II, and III), while two major peaks of $\alpha$-mannosidase $(\cdots)$ were resolved. The solid line denotes the $\mathrm{pH}$ gradient. In the upper panel, the electrofocusing profile of $\beta$-hexosaminidase $(\times-\times)$ and $\beta$-galactosidase ( proportion of $\beta$-hexosaminidase A. 
Sphingomyelinase in cultured Niemann-Pick cells displayed peaks of activity at pI values comparable with those observed in control cells (Fig. 3). However, in types A and B, all of the peaks of activity were substantially reduced. The cells from the proposed case of type $E$ was different since only one of the two major peaks of activity could be discerned, and the total enzyme associated with species I was higher than that observed in normal cells (Fig. 3). The third major peak of activity (III) seen in control cells was present at near normal levels. The relative amounts of the various species are shown in Table 3. Here, the total units of activity in the peak tubes from the electrofocusing experiments are compared with the total protein applied to the column and expressed as the relative specific activity. This normalizes the data since the total amounts of protein applied to the column varied between experiments. It can be seen that the relative amounts of each enzyme species in both A and B cells generally conform to the level of enzyme seen in the total homogenate. Thus, in type A cells, each species is $0.7-1.5 \%$ of the normal level, whereas in type B cells the range is $3-6.6 \%$ of normal.

In the type E cells, species I is about fivefold higher than the normal, species II is absent, and species III is near normal level

\section{DISCUSSION}

Sphingomyelinase has been resolved into three peaks by isoelectric focusing (I, II, III). Peak I has a pI of 4.6, II a pI of 4.8, and III a pl of 5.0. Cultured fibroblasts from Niemann-Pick disease types A and B are characterized by very low levels of sphingomyelinase but in both, the same peaks of enzyme seen in normal cells can be recognized. The major difference in types A and B appears to be the amount of residual sphingomyelinase present. Type B cells were found to have about twice as much activity as type A cells. This result is consistent with observations made by other workers on cultured fibroblasts and on organ samples, such as liver and spleen $(2,12,13)$. The cultured cells from the case of type E gave a sphingomyelinase profile different from normal and the other types. Here, only one (species I) of the major peaks ( $\mathrm{pl}$

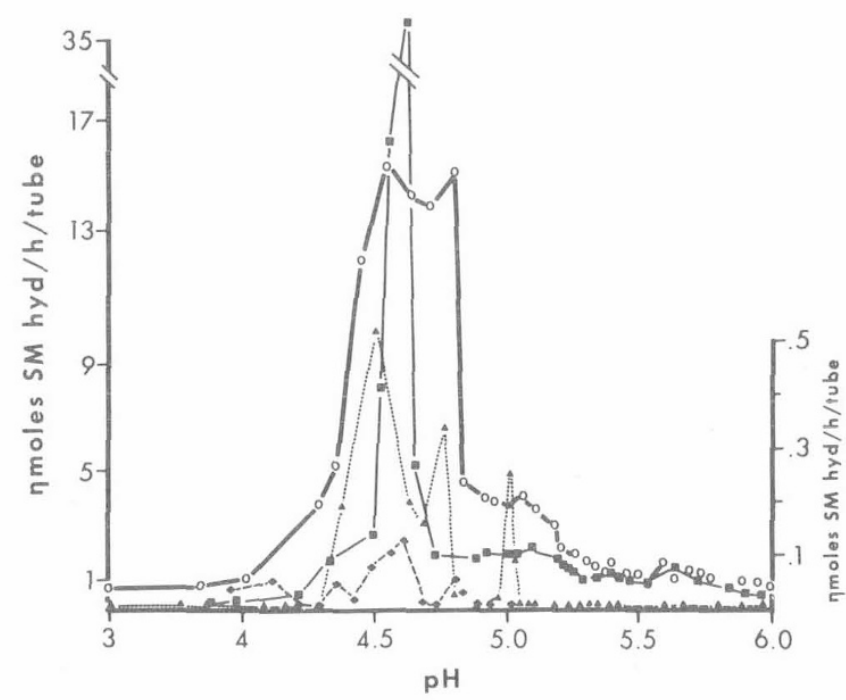

Fig. 3. Sphingomyelinases in fibroblasts from patients with NiemannPick disease. All cells were processed and electrofocused as described. Left ordinate: cells from a normal stain (O_- O) and from type $\mathrm{E}$ (_right ordinate: cells derived from patients with type B $(\mathbf{\Delta} \cdots \mathbf{\Delta})$ and type A (case I, In every instance, the experiments were carried out as shown in Figure 2. Little sphingomyelinase activity was found above $\mathrm{pH}$ 6.0. Total protein applied to the column was $6.7,3.2,3.3$, and $5.8 \mathrm{mg}$ protein for the control and Niemann-Pick disease cells types E, A (case l), and B, respectively. Electrofocusing of cells from type A (case 2) gave the same results as shown for case 1 .
Table 3. Sphingomvelinase activity in peaks obtained by electrofocusing ${ }^{1}$

\begin{tabular}{|c|c|c|c|c|c|c|}
\hline \multirow[b]{2}{*}{ Cell strain } & \multicolumn{2}{|c|}{$\begin{array}{l}\text { Peak I, } \\
\text { pl } 4.6\end{array}$} & \multicolumn{2}{|c|}{$\begin{array}{c}\text { Peak II, } \\
\text { pI } 4.8\end{array}$} & \multicolumn{2}{|c|}{$\begin{array}{l}\text { Peak III, } \\
\text { pl } 5.0\end{array}$} \\
\hline & Units & RSA & Units & RSA & Units & RSA \\
\hline \multicolumn{7}{|l|}{ Control } \\
\hline 1 & 12.1 & 2.8 & 11.6 & 2.7 & 2.0 & 0.5 \\
\hline 2 & 15.4 & 2.3 & 15.2 & 2.3 & 4.2 & 0.6 \\
\hline 3 & 8.5 & 1.7 & 5.8 & 1.1 & 1.9 & 0.4 \\
\hline \multicolumn{7}{|c|}{ Niemann-Pick disease } \\
\hline \multicolumn{7}{|c|}{ Type A } \\
\hline 1 & 0.13 & 0.04 & 0.06 & 0.02 & & \\
\hline 2 & 0.06 & 0.03 & 0.03 & 0.01 & 0.01 & 0.004 \\
\hline Type B & 0.52 & 0.09 & 0.34 & 0.06 & 0.25 & 0.04 \\
\hline Type E & 35.6 & 11.1 & \multicolumn{2}{|c|}{ Absent } & 2.2 & 0.7 \\
\hline
\end{tabular}

${ }^{2}$ The sphingomyelinase activity obtained in peak tubes from the separate experiments was taken. Units: units of activity per tube at the peak height; RSA: relative specific activity which compares the units above to the total amount of protein applied to the column.

4.6) could be recognized, species II (pI 4.8) was absent, but species III was present. Sphingomyelinase I in type E cells was about five-fold higher than the level of species I in the control cells analyzed. The profile seen in this case is reminiscent of the pattern observed in liver from the three cases of type $C$ that we have examined $(3,4)$. We would predict a type E-like sphingomyelinase profile for cultured cells derived from type C patients if, as we proposed, a deficiency of species II represented the specific genetic defect in this disease. It thus appears, although this must be confirmed, that cases of type $\mathrm{C}$ and type $\mathrm{E}$ are related with respect to their genetic defects and are different in this regard from types $\mathrm{A}$ and $\mathrm{B}$. We have previously indicated in one case of type B that all major species of enzyme found in normal liver can be recognized in liver from type $\mathrm{B}$, although their activities are much reduced (4). This result, coupled with the data presented here on cultured type B cells, suggests that predictions on the expected results can be made from tissue to tissue.

The general reduction of all sphingomyelinases in cells from both types A and B suggests that each sphingomyelinase separated by isoelectric focusing is structurally related, perhaps showing a common polypeptide sequence at or near the active site. At the same time, it is possible to encounter a specific deficiency of one major peak, notably, sphingomyelinase II in cultured cells and in other tissues. This suggests that species II, although it shares common structural features with the other enzymes, is under distinct genetic control. It is possible that this is true for each species of sphingomyelinase. Since the various forms of the enzyme have not been well characterized, definition of possible structural interrelationships awaits further studies.

\section{SUMMARY}

Sphingomyelinase activity was reduced to barely detectable levels (1.5\% of normal) in cultured cells from two cases of type A Niemann-Pick disease, whereas in type B cells, the level was $3.4 \%$ of normal. In type E, total activity was twofold higher than normal.

Sphingomyelinases were resolved into three peaks of activity (I-III) by electrofocusing. The isoelectric points were 4.6, 4.8, and 5.0 for peaks I, II, and III, respectively. In type A and B cells, all peaks are present, but drastically reduced, whereas in type $E$ cells, peaks I and III persist while peak II is absent. In types A and $\mathrm{B}$, the genetic defects may be related, whereas the genetic defects in types $\mathrm{C}$ and $\mathrm{E}$ appear to be related, but are distinct from types $\mathrm{A}$ and $\mathrm{B}$. 


\section{REFERENCES AND NOTES}

1. Beutler, E., Kuhl, W., Trinidad, F., Tepliz, R., and Nadler, H.: $\beta$-Glucosidase activity in fibroblasts from homozygotes and heterozygotes for Gaucher's disease. Amer. J. Hum. Gen., 23: 62 (1971).

2. Brady, R. O., Kanfer, J. N., Mock, M. B., and Fredrickson, D. S.: The metabolism of sphingomyelin. II. Evidence of an enzymatic deficiency in Niemann-Pick disease. Proc. Nat. Acad. Sci. U.S.A., 55: 366 (1966).

3. Callahan, J. W., Khalil, M., and Gerrie, J.: Isoenzymes of sphingomyelinase and the genetic defect in Niemann-Pick disease, type C. Biochem. Biophys. Res. Commun.. 58: 384 (1974).

4. Callahan, J. W., Khalil, M., and Philippart, M.: Sphingomyelinases in human tissues. II. Absence of a specific enzyme from liver and brain of Niemann-Pick disease, type C. Pediat. Res., 9: 908 (1975).

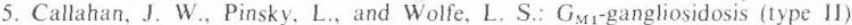
Studies on a fibroblast cell strain. Biochem. Med. 4:295 (1970).

6. Crocker, A. C.: The cerebral defect in Tay-Sachs disease and Niemann-Pick disease. J. Neurochem., 7: 69 (1961).

7. Epstein, C. J., Brady, R. O.. Schneider, E. L., Bradley, R. M.. and Shapiro, D. In utero diagnosis of Niemann-Pick disease. Amer. J. Hum. Gen., 23: 533 (1971)

8. Fredrickson, D. S., and Sloan, H. R.: Sphingomyelin lipidoses: Niemann-Pick disease. In: J. B. Stanbury, J. B. Wyngaarden, and D. S. Fredrickson: The Metabolic Basis of Inherited Disease, Chapt. 35, p. 783 (McGraw-Hill Book Co., New York, 1972).

9. Lowry, O. H., Rosebrough, N. L., Farr, A. L., and Randall, R. J : Protein measurement with the Folin phenol reagent. J. Biol. Chem.. 193: 265 (1951).

10. Lynn, R., and Terry, R. D.: Lipid histochemistry and electron microscopy in adult Niemann-Pick disease. Amer. J. Med., 37: 987 (1964).

11. Robins, E., Hirsch, H. E., and Emmons, S. S.: Glycosidases in the nervous system. I. Assay, some properties and distribution of $\beta$-glucuronidase and $\beta$-glucosidase, J. Biol. Chem., 243: 4246 (1968)

12. Schneider, P. B., and Kennedy, E. P.: Sphingomyelinase in normal human spleens and in spleens from subjects with Niemann-Pick disease. J. Lipid Res. 8: 202 (1967).

13. Sloan, H. R., Uhlendorf, B. W., Kanfer, J. N., Brady, R. O., and Fredrickson, D. S.: Deficiency of sphingomyelin-cleaving enzyme activity in tissue culture derived from patients with Niemann-Pick disease. Biochem. Biophys. Res. Commun.. 34: 582 (1969).

14. Thomas, G. H., Taylor, H. A., Reynolds, L. W., and Miller, C. S.: Mucolipidosis III (Pseudo-Hurler polydystrophy): Multiple lysosomal enzyme abnormalities in serum and cultured fibroblast cells. Pediat. Res., 7: 751 (1973).

15. A detailed clinical description of this patient is in preparation and will be presented elsewhere.

16. St. Louis, Mo

17. Colnbrook, U.K.

18. Bromma, Sweden

19. The authors are indebted to Dr. M. Buchwald and Mrs, Nancy Allen of the Department of Medical Genetics for the fibroblast cultures and Dr. P. Quinn. Department of Bacteriology, who carried out the mycoplasma determinations.

20 Dr J, W. Callahan is a Medical Research Council of Canada scholar.

21. This research was supported by Grant MA-4873 from the Medical Research Council of Canada.

22. Requests for reprints should be addressed to: J. W. Callahan, Ph.D., Hospital for Sick Children, 555 University Ave.. Toronto, Ontario, M5G IX8 Canada.

23. Accepted for publication July 25, 1975
Erythrocyte entrapment $\beta$-glucuronidase

Fabry disease

Gaucher disease lysosomal storage disease

\title{
Enzyme Therapy. V. In Vivo Fate of Erythrocyte-entrapped $\beta$-Glucuronidase in $\beta$-Glucuronidase-deficient mice
}

\author{
SUZANNE R. THORPE, MORRIS B. FIDDLER, AND ROBERT J. DESNICK ${ }^{(40)}$
}

Departments of Pediatrics, Laboratory Medicine, and Pathology and The Dight Institute for Human Genetics, University of Minnesota Medical School, Minneapolis, Minnesota, USA

\section{Extract}

The use of erythrocyte entrapment as a strategy to deliver and protect exogenously administered enzymes for replacement therapy in selected genetic diseases has been evaluated in a mammalian model system. The uptake, tissue distribution, intracellular localization, and in vivo lifetime of erythrocyte-entrapped bovine $\beta$ glucuronidase were determıned by a selective thermal inactivation assay after intravenous administration into $\beta$-glucuronidase-deficient mice. The exogenous activity was cleared from the circulation with a half-life of about $\mathbf{2 0} \mathrm{min}$ and was no longer detectable at $2 \mathrm{hr}$. A concomitant uptake of the injected enzyme was observed in murine tissues, primarily the liver; approximately $30 \%$ of the bovine activity was recovered at $30 \mathrm{~min}$ and maximal hepatic uptake, $71 \%$ of dose, was detected at $2 \mathrm{hr}$. Hepatic recovery of the bovine activity was observed to decrease in a biphasic pattern to nondetectable levels by 5 days. The recovery of the entrapped activity was characterized by a latency of detection in hepatic tissue up to $13 \mathrm{hr}$ postinjection. At each time point more than $80 \%(84$ $100 \%$ ) of the recovered bovine activity was detected in the lysosomally enriched hepatic subcellular fraction. Maximal recoveries of $10 \%$ and $15 \%$ of administered dose were observed in splenic and renal tissues, respectively, soon after enzyme administration. In comparison to results obtained after intravenous administration of unentrapped bovine $\beta$-glucuronidase, erythrocyte-entrapped activity was retained fourfold longer in the circulation, fivefold longer in hepatic tissue, and was more efficiently delivered to a variety of tissues.

\section{Speculation}

Entrapment in autologous erythrocytes may provide an effective means to optimize the delivery and protection of exogenous enzymes for the treatment of selected lysosomal storage diseases, such as Fabry and type 1 Gaucher diseases, by enzyme replacement therapy. Furthermore, efficient delivery to specific target sites of pathology may be accomplished by the entrapment of other therapeutic agents within these biodegradable vesicles.

Exploratory trials of enzyme therapy have been stimulated by advances in the elucidation and characterization of the specific enzymatic defects in an ever increasing number of inborn errors of metabolism $(9,26)$. Since 1964, when Baudhuin and coworkers (3) 